\title{
Altrenogest treatment effects on the reproductive performance of sows during transition to batch farrowing
}

\section{José Luís Corezzolla ${ }^{1}$ Rafael da Rosa Ulguim $^{2}(\mathbb{D})$ Bernardo Garziera Gasperin $^{3}$ (D) Lucio Pereira Rauber ${ }^{1}$ (D) Ivan Bianchi $^{{ }^{*}}$ (D)}

${ }^{1}$ Instituto Federal Catarinense, Blumenau, SC, Brasil.

${ }^{2}$ Setor de Suínos, Departamento de Medicina Animal, Faculdade de Veterinária, Universidade Federal do Rio Grande do Sul (UFRGS), Porto Alegre, RS, Brasil.

${ }^{3}$ Laboratório de Reprodução Animal, Universidade Federal de Pelotas (UFPel), Faculdade de Veterinária, 89245-000, Capão do Leão, RS, Brasil. E-mail: ivan.bianchi@ifc.edu.br. "Corresponding author.

ABSTRACT: The synthetic progestin altrenogest (ALT) has been widely used in sow farms to concentrate artificial inseminations (AIs) during the transition of weekly productive flow for the batch farrowing system of 14 or 21 days. The objective of the present study was to investigate the effect of the duration of ALT treatment on the reproductive performance of weaned sows during transition to batch farrowing. Retrospective data was evaluated regarding the reproductive performance of primiparous and multiparous sows that were either not treated (control, $n=$ 165) or treated with $20 \mathrm{mg}$ ALT during 7 days (ALT7, $n=161)$ or 14 days (ALT14, $n=199)$ post-weaning. The interval between weaning or the end of ALT supplementation and first AI did not differ among the groups, as well as the percentage of sows inseminated up to 7 or 10 days after the end of treatment or weaning $(P \geq 0.16)$. There was a tendency for a lower farrowing rate $(P=0.06)$ in ALT7 (77.2\%) when compared to ALT14 (84.5\%) and control (86.3\%) groups. The total number of piglets born did not differ among groups $(P=0.35)$. In conclusion, despite the slight delay in the estrus onset, the proportion of estrous sows was not affected, whereas the adjusted farrowing rate was reduced when ALT was administered for 7 days after weaning in multiparous sows during transition to 21 days batch farrowing system.

Key words: swine, animals, female, altrenogest, weaning.

Efeito do período de suplementação com altrenogest no desempenho reprodutivo de fêmeas suínas em transição para o manejo em bandas

RESUMO: O progestágeno sintético altrenogest (ALT) tem sido amplamente utilizado na suinocultura para agrupamento da inseminação, na transição de fluxo produtivo semanal para manejo em bandas de 14 ou 21 dias. O presente estudo investigou o efeito da duração do tratamento com ALT sobre o desempenho reprodutivo de fêmeas desmamadas na transição para o manejo em bandas. Foram coletados dados retrospectivos do desempenho reprodutivo de fêmeas primíparas e pluriparas desmamadas $(n=525)$ que não foram tratadas $($ controle, $n=$ 165) ou tratadas diariamente com $20 \mathrm{mg}$ de ALT durante 7 dias (ALT7, $n=161)$ ou 14 dias (ALT14, $n=199)$ pós-desmame. O intervalo entre o desmame ou final da suplementação de ALT e a primeira IA não diferiu entre os grupos, bem como o percentual de fêmeas inseminadas até 7 e 10 dias pós a remoção da suplementação hormonal $(P \geq 0,16)$. Houve uma tendência para menor taxa de parto ajustada $(P=0,06)$ no grupo ALT7 (77,2\%), quando comparada aos grupos ALT14 (84,5\%) e controle (86,3\%). O número total de leitões nascidos não diferiu entre os grupos $(P=0,35)$. Conclui-se que, apesar do pequeno atraso no início do estro, não houve impactos na taxa de manifestação estral. Entretanto, a taxa de parto ajustada foi reduzida quando o ALT foi administrado por sete dias após o desmame na transição para o manejo em bandas de 21 dias.

Palavras-chave: suínos, animais, fêmea, altrenogest, desmame.

The segregation of the production phases in the swine industry using different production flows has improved the productive performance. However, in small swine farms, there is a necessity of mixing weaned piglets from multiple sites to fill a nursery facility. This has an impact on transport logistics and on the health status of the animals. Traditionally, the production flows have considered weekly batches. However, for small sow farms, the number of weaned piglets per week is reduced. In this way, the use of a batch farrowing system with 14, 21, and 28 days interval (BOWN, 2006) 
is an alternative used in the swine industry for increasing the number of weekly weaned piglets. It must be emphasized that the batch farrowing with 21 days of interval allows a lactation period of 28 days, improving the growth rate and reducing stress parameters in piglets (COLSON et al., 2006).

Adjustments to the production flow of sow farms from weekly to a batch farrowing system are possible without the use of hormones, through increasing lactation length, or using a skip-aheat. The latter is difficult to perform due to space limitation and increase in non-productive days. For this reason, the use of hormones to control the estrous cycle is more feasible. Altrenogest (ALT) is the only product commercially available for controlling estrus and ovulation in swine females. It inhibits GnRH release and, consequently, inhibits LH release (VAN LEEUWEN et al., 2015). The ALT treatment must start before the increase of LH pulse frequency, i.e. at or before weaning (PATTERSON et al., 2008). Although, ALT has an inhibitory action on gonadotropin release by the pituitary gland (SOEDE et al., 2007), the suppression of follicle growth is less intense compared to endogenous progesterone (MARTINAT-BOTTE et al., 1985). It is expected that ALT-treated sows present estrus between days 5 and 8 after ALT withdrawal, without negatively affecting the reproductive performance. A meta-analysis was conducted evaluating the duration of treatment with ALT as a strategy for recovering body reserves lost during lactation in primiparous sows (revised by WANG et al. (2018). Negative impacts on reproductive performance after the use of ALT in pluriparous sows were not observed; however, there was no mention of lactation length. Thus, the hypothesis of this study is that treatment with ALT for different periods did not affect the reproductive performance of swine females submitted to lactation length closer to 28 days before treatment. To the best of our knowledge, there are no studies evaluating the impact on reproductive performance after the use of ALT for adjustment of batches of weaned sows. Therefore, this study aimed to evaluate the effect of a 7- or 14-day ALT treatment on the reproductive performance of primiparous and pluriparous sows during transition from weekly flow to batch farrowing system of 21 days.

Retrospective data for the period from February to July 2017 from two commercial sow farms with an inventory of 500 females per farm (F1 Landrace x Large White) were analyzed. The information was extracted from the database of the farms (Agriness S2 Commercial, Brazil) during the transition period from weekly flow to a 21-day batch farrowing system. A total of 525 weaned sows from parity 1 to 10 (P1-10), submitted to a lactation length ranging from 25 to 31 days, with a total of 4 to 26 piglets born and 5 to 16 weaned piglets in the previous farrowing, were randomly distributed in the following groups: Control (no altrenogest, $n=165$ ), ALT7 (Altrenogest - Regumate ${ }^{\circledR}$ MSD Saúde Animal, Brazil) 20mg daily for 7 days, $\mathrm{n}=161$ ) and ALT14 (Altrenogest $20 \mathrm{mg}$ daily for 14 days, $\mathrm{n}=199$ ).

After weaning (control) and on the day of ALT withdrawal (ALT7 and ALT14), estrus detection was performed twice a day using a fence-line boar exposure and back-pressure test. Sows were first inseminated $12 \mathrm{~h}$ after estrus detection and at 24-h intervals during the period of standing estrus (2.3 $\pm 0.5 \mathrm{AI} /$ sow on average). Post-cervical AIs were performed with homospermic semen doses $\left(1.5 \times 10^{9}\right.$ sperm cells in $50 \mathrm{~mL}$ ) produced in the company's boar stud and evaluated after dilution using the Sperm Vision (Minitube).

The following variables were evaluated: weaning-to-estrus interval (WEI); the interval between the end of altrenogest treatment and the first AI; the percentage of sows inseminated until 7 and 10 days after weaning or altrenogest withdrawal; farrowing rate (FR); adjusted farrowing rate (AFR; excluding gestational losses for non-reproductive reasons) and; the total number of piglets born (TPB). In the database, only sows with estrus expression until 65 days post-weaning or altrenogest withdrawal were considered, excluding sows culled for anestrus. All the sows were included in the analysis related to estrus expression. For the analysis of reproductive performance, only sows inseminated until 10 days after weaning or ALT withdrawal were included. The software Statistical Analysis System (SAS Inst. Inc., Cary, NC) was used for analysis. Continuous variables were analyzed using the MIXED procedure and comparisons of means were performed by the Tukey-Kramer test. Frequency variables were analyzed by logistic regression using the GLIMMIX procedure. The group was considered as fixed effect and the farm was included in the model as a random effect. Differences were considered at $\mathrm{P} \leq 0.05$.

No differences among groups in parity (3.7 $\pm 0.1)$, previous TPB $(13.7 \pm 0.1)$, weaned piglets $(10.4 \pm 0.1)$ and lactation length $(28.1 \pm 0.1$ days $)$ were observed $(\mathrm{P} \geq 0.47)$, showing the homogeneity of groups prior to treatment onset. The interval between weaning and the first AI was different among groups $(\mathrm{P}<0.01$, Table 1), confirming the effectiveness of ALT treatment for regulating the estrous cycle (SOEDE et al., 2007; PATTERSON et al., 2008). The 
interval between weaning or ALT withdrawal and the first AI was not different among groups $(\mathrm{P}=0.53)$. However, a higher proportion of sows inseminated on day 4 was observed in the control group $(50.3 \%)$ compared to ALT7 (35.4\%) and ALT14 (31.2\%). On day 6 , a higher percentage of inseminated sows was observed in the ALT groups (ALT7: 9.1\%; ALT14: $8.7 \%)$ compared to the control $(2.0 \%)(\mathrm{P}<0.01)$. The cumulative frequency of inseminated sows on days 4,5 , and 6 was higher in the control group compared to ALT7 and ALT14 groups $(\mathrm{P} \leq 0.05)$, whereas from day 7 onwards, no difference was observed among groups $(\mathrm{P} \geq 0.16$, Table 1$)$.

The FR was not affected by treatments ( $P$ $=0.14)$; however, there was a tendency $(\mathrm{P}=0.06)$ for a lower AFR in the ALT7 group (77.2\%) compared to the control (86.3\%) and ALT14 groups (84.5\%). No significant differences among groups were observed for TPB $(\mathrm{P}=0.35)$. However, multiplying the TPB by AFR resulted in a piglet index of 1156,1058 , and 1191 piglets produced for every 100 inseminated sows in the control, ALT7, and ALT14 groups, respectively. Therefore, in the ALT7 group, treatment resulted in a reduction of approximately $10 \%$ of piglets produced in relation to the other groups. Previous studies evaluated ALT supplementation in primiparous sows to induce a longer WEI, allowing the recovery of body reserves lost during lactation (VAN LEEUWEN et al., 2010; VAN LEEUWEN et al., 2011; WERLANG et al., 2011; VAN LEEUWEN et al., 2015). However, in this study, ALT supplementation aimed to synchronize the estrus and insemination of weaned primiparous and pluriparous sows during the transition period for a batch farrowing system of 21 days. Therefore, a better reproductive performance of supplemented sows as suggested by WANG et al. (2018), was not expected. Similarly, a reduction in AFR in sows treated with ALT for 7 days (ALT7) during the transition period for a batch farrowing was not expected; although, it was demonstrated in other studies with different approaches. It is noteworthy that there was no significant interaction between parity and treatment in relation to variables of reproductive performance evaluated in this study.

Two important parameters in the transition to batch farrowing system are the resumption of cyclicity in sows that were hormonally treated and the estrus synchrony until day 7 post-weaning or altrenogest withdrawal. These were observed in the present study regardless of the period of

Table 1 - Reproductive performance of weaned sows not-treated (control) or treated with altrenogest for 7 or 14 days post-weaning during transition to 21 days batch farrowing system.

\begin{tabular}{|c|c|c|c|c|}
\hline Variables & Control & ALT7 & ALT14 & P-value \\
\hline Sows, $\mathrm{n}$ & 165 & 161 & 199 & \\
\hline Weaning to AI interval, $\mathrm{d}$ & $6.2 \pm 0.6^{\mathrm{a}}$ & $14.2 \pm 0.7^{\mathrm{b}}$ & $20.7 \pm 0.7^{\mathrm{c}}$ & $<0.01$ \\
\hline Weaning/ALT withdrawal interval to AI, $\mathrm{d}^{*}$ & $6.2 \pm 0.6$ & $7.2 \pm 0.7$ & $6.7 \pm 0.7$ & 0.53 \\
\hline AI up to $4 \mathrm{~d}, \% *$ & $\begin{array}{c}66.3^{a} \\
(132 / 199)\end{array}$ & $\begin{array}{c}44.7^{b} \\
(72 / 161)\end{array}$ & $\begin{array}{c}50.9^{b} \\
(84 / 165)\end{array}$ & $<0.01$ \\
\hline AI up to $5 \mathrm{~d}, \% *$ & $\begin{array}{c}87.9^{\mathrm{a}} \\
(175 / 199)\end{array}$ & $\begin{array}{c}73.3^{b} \\
(118 / 161)\end{array}$ & $\begin{array}{c}73.3^{b} \\
(121 / 165)\end{array}$ & $<0.01$ \\
\hline AI up to $6 \mathrm{~d}, \% *$ & $\begin{array}{c}89.9^{\mathrm{a}} \\
(179 / 199)\end{array}$ & $\begin{array}{c}82.0^{\mathrm{b}} \\
(132 / 161)\end{array}$ & $\begin{array}{c}82.4^{\mathrm{b}} \\
(136 / 165)\end{array}$ & 0.05 \\
\hline AI up to $7 \mathrm{~d}, \% *$ & $\begin{array}{c}90.1 \\
(181 / 199)\end{array}$ & $\begin{array}{c}85.7 \\
(138 / 161)\end{array}$ & $\begin{array}{c}85.5 \\
(141 / 165)\end{array}$ & 0.20 \\
\hline AI up to $10 \mathrm{~d}, \% *$ & $\begin{array}{c}91.5 \\
(182 / 199)\end{array}$ & $\begin{array}{c}86.3 \\
(139 / 161)\end{array}$ & $\begin{array}{c}92.1 \\
(152 / 165)\end{array}$ & 0.16 \\
\hline Farrowing rate, $\%$ & $\begin{array}{c}83.0 \\
(151 / 182)\end{array}$ & $\begin{array}{c}75.5 \\
(105 / 139)\end{array}$ & $\begin{array}{c}82.2 \\
(125 / 152)\end{array}$ & 0.14 \\
\hline Adjusted farrowing rate, $\%$ & $\begin{array}{c}86.3^{a} \\
(151 / 175)\end{array}$ & $\begin{array}{c}77.2^{\mathrm{b}} \\
(105 / 136)\end{array}$ & $\begin{array}{c}84.5^{\mathrm{ab}} \\
(125 / 148)\end{array}$ & 0.06 \\
\hline Total piglets born, $\mathrm{n}$ & $13.4 \pm 0.4$ & $13.7 \pm 0.5$ & $14.1 \pm 0.5$ & 0.35 \\
\hline
\end{tabular}

Control: non-treated weaned sows; ALT7 and ALT 14: sows daily treated with $5 \mathrm{~mL}$ ( $20 \mathrm{mg}$ of altrenogest) by oral route for 7 or 14 days post-weaning. The first artificial insemination (AI) was performed $12 \mathrm{~h}$ after estrus detection; ${ }^{\text {a-c }}$ Indicate significant difference in the same row. "Interval from weaning date (control) or the last day of altrenogest treatment to the first AI. Data presented in percentages or mean \pm standard error. 
supplementation. Our results differed from those reported by PATTERSON et al. (2008), wherein it was observed that treatment with ALT for 14 days increased the percentage of estrus expression until 10 days after hormone withdrawal, compared with sows supplemented for 7 days. The proportion of estrous in primiparous sows was also reduced after ALT treatment for 5 days compared to non-treated sows in the first or second estrus post-weaning (WERLANG et al., 2011). In these studies ALT was administered in sows submitted to a lactation length of 21 days, whereas in the present study the lactation length averaged 28 days, which can influence follicle size at weaning (VAN LEEUWEN et al., 2011). The evaluation of follicular dynamics could provide a greater insight into the observed results, as it was previously demonstrated that ALT treatment for short-periods (4 to 8 days) was beneficial to weaned primiparous sows with small follicles but had a detrimental effect for weaned sows with large follicles (VAN LEEUWEN et al., 2011).

In general, the FR and TPB in the evaluated farms were below the expected for Brazilian farms. However, the results of the control group are within the average values observed for Brazilian farms (AGRINESS, 2018). Although, a reduction in AFR had been observed in the sows treated with ALT for 7 days, the FR and TPB were superior to those observed by WERLANG et al. (2011), in which primiparous sows were treated with ALT during 5 days after weaning. In primiparous sows, the FR post-treatment with ALT during 8 days was lower than that observed after treatment for 15 days (VAN LEEUWEN et al., 2011). The positive effects of the longer treatment with ALT in primiparous sows from previous studies can be explained by the recovery of body condition scores. However, in the present study, a better reproductive performance was observed in weaned sows that were not hormonally treated, thereby refuting that hypothesis.

The TPB was not affected by the duration of treatment with ALT, which is in accordance with the study by VAN LEEUWEN et al. (2011), in which no significant difference was observed in the number and quality of embryos in non-treated primiparous sows and sows treated with ALT for 8 or 15 days. However, the use of ALT for 14 days in primiparous sows increased the number of fetuses at day 50 of gestation compared to sows treated with ALT for 7 days and non-treated sows (PATTERSON et al., 2008). In both studies the FR and TPB were not evaluated because the sows were slaughtered. An increase in the TPB and piglets born alive was observed in primiparous sows treated with ALT for 15 days compared with sows not treated or treated with ALT for 4 or 8 days (VAN LEEUWEN et al., 2011). It is important to emphasize that primiparous sows tend to have a lower reproductive performance and the beneficial effect of the ALT treatment period could be related to the recovery of the weight lost during the lactation period.

In fact, during the transition period for a batch farrowing system, the use of ALT for 7 days is necessary. However, the impact on reproductive performance is limited to this period of transition of production flow. Thus, in conclusion, the use of ALT for 7 or 14 days post-weaning in primiparous and pluriparous sows did not affect the percentage of estrous sows until 7 or 10 days after weaning. Furthermore, both the FR and TPB are not affected. However, the AFR is reduced in sows treated with ALT for 7 days in the period of transition for a batch farrowing system of 21 days. Further research is, therefore, needed to determine the factors associated with reproductive losses observed after the use of ALT for 7 days to circumvent this problem.

\section{ACKNOWLEDGMENTS}

Authors are grateful to Conselho Nacional de Desenvolvimento Científico e Tecnológico (CNPq), Fundação de Amparo à Pesquisa do Estado do Rio Grande do Sul (FAPERGS) (PRONEX 12/2014, 16/2551-0000494-3) and Coordenação de Aperfeiçoamento de Pessoal de Nível Superior (CAPES) (finance code 001).

\section{BIOETHICS AND BIOSSECURITY COMMITTEE APPROVAL}

Institutional Animal Care and Use Committee of the Instituto Federal Catarinense Campus Araquari (Protocol 176/2016).

\section{DECLARATION OF CONFLICT OF INTERESTS}

The authors declare no conflict of interest. The founding sponsors had no role in the design of the study; in the collection, analyses, or interpretation of data; in the writing of the manuscript, and in the decision to publish the results.

\section{AUTHORS' CONTRIBUTIONS}

All authors contributed equally for the conception and writing of the manuscript.

\section{REFERENCES}

AGRINESS. Relatório Anual do Desempenho da Produção de Suínos 2018. Available from: <http://145jiolp 
2h9417125d2acd6p.wpengine.netdna-cdn.com/wp-content/ uploads/2019/05/relatorio_melhores_da_suinocultur_11ed. pdf>. Accessed: Oct. 8, 2019.

BOWN, P. Advantages and disadvantages of batch farrowing. In practice, v.28, p.94-96. 2006. Available from: $<$ https://inpractice. bmj.com/content/28/2/94>. Accessed: Oct. 8, 2019.

COLSON, V., et al. Consequences of weaning piglets at 21 and 28 days on growth, behaviour and hormonal responses. Applied Animal Behaviour Science, v.98, n.1-2, p.70-88 2006. Available from: <http://www.sciencedirect.com/science/ article/pii/S0168159105002534>. Accessed: Oct. 08, 2019. doi: 10.1016/j.applanim.2005.08.014.

MARTINAT-BOTTE, F., et al. Control of pig reproduction in a breeding programme. J Reprod Fertil Suppl, v.33, p.211-28. 1985. Available from: <https://pubmed.ncbi.nlm.nih.gov/3910826/>. Accessed: Oct. 08, 2019.

PATTERSON, J., et al. Responses to delayed estrus after weaning in sows using oral progestagen treatment. J Anim Sci, v.86, n.8, p.1996-2004. 2008. Available from: <https://www.ncbi.nlm.nih. gov/pubmed/18407977>. Accessed: Oct. 08, 2019. doi: 10.2527/ jas.2007-0440.

SOEDE, N. M., et al. Follicle development during luteal phase and altrenogest treatment in pigs. Reprod Domest Anim, v.42, n.3, p.329-32. 2007. Available from: <https:/www.ncbi.nlm.nih.gov/ pubmed/17506814>. Accessed: Oct. 08, 2019. doi: 10.1111/j.14390531.2006.00779.x.
VAN LEEUWEN, J. J., et al. Follicle size and reproductive hormone profiles during a post-weaning altrenogest treatment in primiparous sows. Reprod Fertil Dev, v.27, n.2, p.304-12. 2015. Available from: $<$ https://www.ncbi.nlm.nih.gov/pubmed/24192203>. Accessed: Oct. 08, 2019. doi: 10.1071/RD13149.

VAN LEEUWEN, J. J., et al. Post-weaning Altrenogest treatment in primiparous sows; the effect of duration and dosage on follicular development and consequences for early pregnancy. Anim Reprod Sci, v.119, n.3-4, p.258-64. 2010. Available from: <https://www. ncbi.nlm.nih.gov/pubmed/20223607>. Accessed: Oct. 08, 2019. doi: 10.1016/j.anireprosci.2010.02.008.

VAN LEEUWEN, J. J., et al. The effect of different postweaning altrenogest treatments of primiparous sows on follicular development, pregnancy rates, and litter sizes. JAnim Sci, v.89, n.2, p.397-403. 2011. Available from: <https://www.ncbi.nlm.nih.gov/pubmed/20952527>. Accessed: Oct. 08, 2019. doi: 10.2527/jas.2010-3246.

WANG, Z., et al. Effects of altrenogest on reproductive performance of gilts and sows: A meta-analysis. Anim Reprod Sci, v.197, p.10-21. 2018. Available from: <https:/www.ncbi. nlm.nih.gov/pubmed/30197055>. Accessed: Oct. 08, 2019. doi: 10.1016/j.anireprosci.2018.08.035.

WERLANG, R. F., et al. Effects of breeding at the second oestrus or after post-weaning hormonal treatment with altrenogest on subsequent reproductive performance of primiparous sows. Reprod Domest Anim, v.46, n.5, p.818-23. 2011. Available from: $<$ https://www.ncbi.nlm.nih.gov/pubmed/21323753>. Accessed: Oct. 08, 2019. doi: 10.1111/j.1439-0531.2010.01747.x. 